\title{
REQUIREMENTS FOR DESIGNING EFFECTIVE CLIMATE CHANGE GAME
}

\author{
Nurlieda Ellyanna Munirrah Razali ${ }^{1}$, Nor Azan Mat Zin ${ }^{1}$, Mohamad Pauzi Zakaria ${ }^{2}$, \\ Tengku Siti Meriam Tengku Wook ${ }^{1}$, Norizan Mat Diah ${ }^{3}$ and Fadhilah Rosdi ${ }^{1}$ \\ ${ }^{1}$ Faculty of Technology and Information Science, Universiti Kebangsaan Malaysia \\ 43600 UKM BANGI, Selangor, Malaysia \\ ${ }^{2}$ Institute of Ocean and Earth Sciences(IOES), University of Malaya, Malaysia \\ ${ }^{3}$ Faculty of Computer Science and Mathematics, Mara University of Technology, Malaysia
}

\begin{abstract}
Climate continues to change as a result of global warming but awareness and positive behavior are still low despite efforts to educate and engage the public through campaigns and education. Therefore, interactive games which provide simulated experience can be effective to promote engagement, especially among youth who are less concerned about the environment and less likely to engage in environmentally responsible actions. This paper presented a study on the requirements gathering for a serious game design on climate change (CC) that contextualize the processes in carbon cycle as the main story. Further literature analysis on $\mathrm{CC}$ issues and existing $\mathrm{CC}$ games that have the element of climate change were carried out to identify gaps and propose a design solution for a new $\mathrm{CC}$ game. The findings show that the requirements for $\mathrm{CC}$ game include correct information (content), aesthetic pleasure, quizzes, rewarding mechanisms, rules, goals leaderboard, performance graph and badges.
\end{abstract}

\section{KEYWORDS}

Serious Game, Climate Change, Carbon Cycle, Requirements, Game Design

\section{INTRODUCTION}

Global climate continues to change over the past 50 years as a result of global warming. Climate system data show that human activities rapidly change many aspects of the global climate and that the Earth is warming (Walsh et al. 2014). Nevertheless, awareness of climate change issues among Malaysians is still low, therefore there is a need to enhance awareness which should start at an early age (Shahiddan 2014; Aqilah 2018, Shahino 2018). Some society leaders suggested education at primary school level to change citizens' attitude and empower importance of green technology among the people (Aqilah 2018). Global warming, energy issues and greenhouse effect are interdependent environmental issues that lead to climate change thus need to be addressed for sustainability.

Locally, here have been increasing efforts by the government, private sectors and non-governmental organisations (NGOs) to educate and engage the public on environmental issues through various campaigns and formal education approach, such as the Annual program for 3R -waste to Art competition sustainable green campus convention, setting-up an annual National level recycle day on 11th November, School recycling competition (PerKiSS) and community driven programs like recycling bank in community (3R@com). The ministry of Science and Innovation (MESTECC) together with Education ministry, Department of Society Progress (Kemas) and the National Department for Integration (JPNIN) developed a Teaching and learning module for 3R practices and solid waste management for preschool which is used in 5,228 preschools across the nation starting 2018. For the primary and secondary schools, SWCorp has introduced a training module for recycling since 2014 . However, awareness and behavior change regarding positive responses to climate change is still low among the population. 
Recent studies also confirmed that many climate communications efforts have failed due to uni directional transmission of information that made audience passive consumers of information, lack of contextualization which cause confusion with other environmental issues and the negative and alarmist tone of the content, which often evokes paralysis or apathy instead of motivating people to take action (Ouariachi, Olvera-Lobo, \& Gutiérrez-Pérez 2017). Serious Games are digital games that providing the purpose to create awareness of a certain issue, to change behavior or to teach simultaneously with entertainment (Alonso-fernandez et al. 2017). In addition, gaming increases the sense of personal responsibility, the confidence in politics for climate change mitigation, and makes players more optimistic about international cooperation in climate politics (Meya, \& Eisenack 2018). It is important to start teaching young people to bring change regarding the CC issues using the current technology such as games to engage them. Furthermore, quantitative evidence on the effectiveness of a simulation game for communicating and teaching international climate politics showed that the game facilitates experiential learning about the difficulties of international climate politics.

Young people have the potential to trigger an ambitious and long-term societal change, adopting sustainable attitudes and behaviors in energy use from early ages and influencing their parents' decisions (Ouariachi, Olvera-Lobo, \& Gutiérrez-Pérez 2017). However, Bofferding and Kloser (2015) opined that awareness and commitment are still limited with 'Youth' who is even less concerned about the environment than older age-groups and less likely to engage in environmentally responsible actions. 'Youth' belongs to digital generation, hence interactive games which can provide immersive, real time simulated experience, should be employed for climate change engagement, complementing factual persuasion - presenting climate change facts through conventional methods such as school curriculum, campaigns using printed materials or mass media which fail to change many people's actions due to ideological and other intractable resistances.

Available games have content issues in the way games model the human-environment relationship, either environment as backdrop, resource, antagonist or text are only frameworks for players action and aesthetic pleasure (Abraham \& Jeyamanne 2017). Most games focus on practices such as recycling or reducing waste but very few focuses on mechanisms and processes that cause anthropogenic climate change although some games discuss long-term climate effects. However, only recently there have been a few games employing carbon cycle as the content for $\mathrm{CC}$ games Hence our research aims to gather requirements for effective CC game, focusing on game elements that contextualize the process of carbon cycle disruptions as the main story of the game.

\section{CARBON CYCLE}

Climate change occurs due to the release of excess greenhouse gases such as carbon dioxide $\left(\mathrm{CO}^{2}\right)$, nitrous oxide and methane as a result of industrial and agricultural waste. The effect of greenhouse gases in the atmosphere captures heat, which in turn causes an increase in the temperature of the earth. Consequently, extreme weather and global warming are due to excessive greenhouse gas emissions (Sau, Weng, \& Ahamad 2016). Global $\mathrm{CO}^{2}$ emissions from human activities have increased by $400 \%$ since 1950 [https://www.thecc.org.uk/tackling-climate-change/the-science-of-climate-change/climate-variationsnatural-and-human -factors /] and more than 40\% compared to pre-industrial levels (Galloway et al.2014).

Furthermore, rapid urbanization in pursuit of a better quality of life has led Malaysia to shift towards environmental degradation as a result of some challenges from environmental issues (Sau, Weng, \& Ahamad 2016). Extreme climates can affect the structure, composition and function of inland ecosystems and can therefore affect regional carbon cycles, potentially leading to the transition from carbon sequestration to carbon sources (Frank 2015). One of the main causes of global climate change has been identified as increasing carbon emissions and our daily actions are among the contributors to the greenhouse gas collection process in the atmosphere (Zou, Mustafa, \& Eid 2015). $\mathrm{CO}^{2}$ remains the major anthropogenic greenhouse gas that accounted for $76 \%$ of total gas emissions in 2010 (Rolle 2018).

In addition, the ocean absorbs about $30 \%$ of the anthropogenic $\mathrm{CO}^{2}$ released into the atmosphere to help mitigate the effects of climate change. However, $\mathrm{CO}^{2}$ hydrolysis in seawater results in an increase in the concentration of hydrogen ions and this would result in the progressive acidification of the oceans (Rolle 2018). The global action to address the issue of climate change (known as the Paris Agreement) aims to ensure that global warming in this century is below 2 degrees Celsius above pre-industrial levels and will continue efforts to limit temperatures to as low as 1.5 degrees Celsius (Wyrwa 2018). 
The challenge of designing a carbon cycle CC game is to understand and then contextualize the fundamental processes of carbon cycle that contribute to the $\mathrm{CC}$. As further game requirements, previous and available games were also analysed.

\section{GAME ANALYSIS}

None of the 'environmental games' apply the whole carbon cycle as the main context of the game, as indicated in Table 1. Among the 11 games, Carbon Command represented one process in the carbon cycle but only focused on $\mathrm{CO}^{2}$ and photosynthesis of plants. While neglecting other elements in carbon cycle such as respiration and decomposition which are necessary to understand the causes of CC. Carbon on our planet is stored in the major sinks which are atmosphere, soil organic matter, ocean, marine sediments and sedimentary rocks, terrestrial plant and fossil fuel deposits (Pidwirny, 2006). The CC game should implement all processes of carbon cycle to further players' understanding. Many CC games focus on climate protection with a major focus on international consultation and local technology for greenhouse gas reduction and there are less games that consider adaptation to climate change (Reckien \& Eisenack 2015). Thus, one requirement of CC game is to contextualize the whole processes of carbon cycle as the main story of the game.

The effectiveness of a game to convey useful information to the players doesn't necessarily depend on a mesmerizing design solely but the accuracy of the game content itself and how it is represented to the players. The correct information given to the players are of concern to the game developers (Foltz et al. 2019). A combination of good design and context will strengthen the effectiveness of the game. Foltz et al. stated that to communicate the complexities of climate change, a simulation type of game is especially well suited as it permits for the simulation of a complex system and allows players' interaction with the system. Games can be a medium to educate people about the carbon cycle and climate change. People can have fun while learning so that they will not feel pressured to process the knowledge all the way through the game. The overall games as mentioned in Table 1 possess the aesthetic pleasure and good context in the game design. the relevancy of a game design for education is how it can be abstracted to convey project curriculum development more widely, apart from creative, communication and project management competencies exposed in the game design process (Shoop \& Lucas 2019). Sailer et al. (2017) also stated that aesthetic value and quality of the design implementations in the game design can affect the players' psychological need satisfaction. Table 1 shows that On Thin Ice, Climate Cards and Urban Climate Architect are among of the examples of simple games yet meaningful as it explains the effect of global warming to the Earth through the game. Hence, the second requirement for $\mathrm{CC}$ game is to possess the combination of aesthetic pleasure and a good information on the whole processes of carbon cycle.

Moreover, players need motivation to play a game on their own will. Without the motivation players will neglect the game and the game failed to achieved its goal. Enjoyment is not the factor that can motivate players willingness to learn while playing serious game but expectations of usefulness and ease of use are the factors that will raise their motivation, in this way serious game should be fun and engaging (Iten \& Petko 2016). In order to get the players' motivation to play CC game, the game should provide ease of use and expectations of usefulness to the players. The players will learn about Carbon cycle while engaging and having fun throughout the game. The use of quizzes in the game may increase the players' motivation and understanding according to the issues that become the focus of the game. A quiz game can be a tool to boost reflection process which is considered as an important bridge between learning and knowledge (Videnovik et al. 2018). Games as indicated in Table 1 which applying quiz in the game designs are Carbon Runner and Carbon Command. These games also rewarding the players if they answer the quiz correctly. Due to the fact, the next requirement for CC game is to apply the quiz concept into the game in order to stimulate players' motivation and understanding.

Furthermore, the character design is important in a game design because the character carry the role as an ambassador of the message and the idea that is portrayed by the game makers (Zufri, Hilman \& Pratama 2016). Zufri, Hilman and Pratama also stated that the game character is the representation of ourselves as a part of the game and the success of a game is usually determined by it. For example, Carbon Runner and Carbon Command use 'Green Ninja' as the avatar of the game while Oxygen Not Included provide 'duplicants' as the avatar. Players emotional state is very important to be considered in the CC game design process as it is the element that can promote players' engagement while playing the game. Sekhavat stated that rewarding mechanism is a crucial part of the game design which can directly affect the game experience in order to 
promote a desired behavior in serious game. Players' playing experience can be improve by rewarding framework as it can affect the players' emotional state and their behavior (Sekhavat 2019). To stimulate desired learning outcomes, the use of design elements, such as narrative context, rules, goals, rewards, multisensory cues, and interactivity seems necessary (Dondlinger 2014). Hence, CC game's requirement is to add rewarding mechanism, rules and goals to improve players' emotional state and behavior.

In addition, competence, satisfaction and perceived task meaningfulness of the players can be triggered by the use of leaderboards, performance graphs and badges while experiences of social relatedness can be affected by the use of meaningful stories, avatar and teammates in the game design (Sailer et al. 2017). As mentioned in Table 1, games such as Block'Hood, Eco, Carbon Runner, Carbon Command, Rise of Industry, Oxygen Not Included, Cities Skyline, and SimCity 4 provide the players with the rewarding mechanism, rules, goals, leaderboards and more to stimulate players' learning outcomes. Therefore, there is a requirement for the CC game to implement leaderboard, performance graph and badge in the game design in order to trigger players' satisfaction, and perceived task meaningfulness.

Table 1. Game with Climate Change Analysis

\begin{tabular}{|c|c|c|c|c|}
\hline Game & Story & Gameplay & Challenges & Carbon Cycle Element \\
\hline $\begin{array}{l}\text { Bock'Hood, by } \\
\text { Plethora } \\
\text { Project } \\
\text { (Plethora } \\
\text { Project, 2016) }\end{array}$ & $\begin{array}{l}\text { "Player creations will } \\
\text { attract inhabitants, } \\
\text { both humans and } \\
\text { animals, that will } \\
\text { populate your } \\
\text { neighborhood. It is the } \\
\text { hands of the player to } \\
\text { provide a positive } \\
\text { environment for } \\
\text { inhabitants to prosper" }\end{array}$ & $\begin{array}{l}\text { "Envision a neighborhood, } \\
\text { by building structures out of } \\
\text { a catalog of } 200+\text { blocks" }\end{array}$ & $\begin{array}{l}\text { "The player is } \\
\text { challenged to maintain } \\
\text { an ecological balance } \\
\text { as each block placed } \\
\text { will consume and } \\
\text { produce resources of } \\
\text { different kinds } \\
\text { Blocks that are not } \\
\text { provided of their } \\
\text { required input, will } \\
\text { slowly decay and } \\
\text { deteriorate to a point } \\
\text { of collapse" }\end{array}$ & $\begin{array}{l}\text { Block'hood doesn't } \\
\text { specifying about carbon } \\
\text { cycle, the gameplay that is } \\
\text { produced by the developer } \\
\text { can educate player on what } \\
\text { is the effect of their action } \\
\text { on the available resources }\end{array}$ \\
\hline $\begin{array}{l}\text { ECO, by } \\
\text { Strange Loop } \\
\text { Games } \\
\text { (Strange Loop } \\
\text { Games, 2017) }\end{array}$ & $\begin{array}{l}\text { "Eco is an online } \\
\text { game where players } \\
\text { must collaborate to } \\
\text { build a civilization in } \\
\text { a world where } \\
\text { everything they do } \\
\text { affects the } \\
\text { environment. All } \\
\text { resources come from a } \\
\text { simulated ecosystem, } \\
\text { with thousands of } \\
\text { plants and animals } \\
\text { simulating 24/7" }\end{array}$ & $\begin{array}{l}\text { Creating virtual planet's } \\
\text { civilization }\end{array}$ & $\begin{array}{l}\text { "Work together } \\
\text { through the player-run } \\
\text { government and } \\
\text { economy to build the } \\
\text { technology to stop a } \\
\text { meteor on a collision } \\
\text { course with the planet, } \\
\text { without polluting the } \\
\text { world and killing it off } \\
\text { in the process before } \\
\text { that even happens" }\end{array}$ & $\begin{array}{l}\text { "Like the real world, the } \\
\text { environment is fragile. } \\
\text { Chop down forests and } \\
\text { wildlife faces extinction; } \\
\text { pollute the air and } \\
\text { temperatures will rise" } \\
\text { (Wallis, 2017). The } \\
\text { element of carbon cycle is } \\
\text { not clearly shown but the } \\
\text { effect from players' action } \\
\text { in the game shows that it } \\
\text { contributes to climate } \\
\text { change }\end{array}$ \\
\hline $\begin{array}{l}\text { Carbon Runner } \\
\text { by Pew Pew } \\
\text { studios } \\
\text { (Green Ninja, } \\
2018 \text { ) }\end{array}$ & $\begin{array}{l}\text { "Carbon Runner is a } \\
\text { fast-paced game } \\
\text { focusing on how } \\
\text { personal decisions } \\
\text { positively or } \\
\text { negatively affect the } \\
\text { environment" }\end{array}$ & $\begin{array}{l}\text { "The endless runner game } \\
\text { lets players jump and punch } \\
\text { as a green ninja sent to } \\
\text { make the world a greener } \\
\text { place to live. They } \\
\text { encounter things that are } \\
\text { both good for the } \\
\text { environment (worth } \\
\text { collecting) and bad for the } \\
\text { environment (for punching). } \\
\text { Quizzes and databases teach }\end{array}$ & $\begin{array}{l}\text { "Collect or destroy } \\
\text { items, which can be } \\
\text { good or bad for the } \\
\text { environment } \\
\text { Correctly answering } \\
\text { questions allows the } \\
\text { player to gain the } \\
\text { powers to advance to } \\
\text { higher levels" }\end{array}$ & $\begin{array}{l}\text { "Carbon Runner helps } \\
\text { teach kids about climate } \\
\text { change and implementing } \\
\text { sustainable practices to } \\
\text { make the Earth a better } \\
\text { place". It does not focus on } \\
\text { carbon cycle process, but it } \\
\text { did teach the players by } \\
\text { giving quiz when they hit } \\
\text { the wrong element for the } \\
\text { environment }\end{array}$ \\
\hline
\end{tabular}

helping them to make environmentally friendly

decisions"

(Wyers, 2016) 
Urban Climate "Urban Climate

Architect, by Architect is an

Clisap educative flash game

(Games4 that allows you to

sustainability) create your own

environmental-

friendly city."

\section{Carbon \\ Command (Green Ninja, 2018)}

Climate Cards "A deck-building by Hopeless game where you play Production cards to exploit a (Hopeless small ecosystem while Production, avoiding destruction 2018) as long as possible"
On Thin Ice by "On Thin Ice is a Karn Bianco short game about the (Karn Bianco, climate crisis, what its 2018) impacts might look like, and what we can do to stop the worst of it right now. With the help of a timetravelling polar bear (Nanuq)"

Rise of Industr. "Rise of Industry is a by Dapper strategic tycoon game Penguin Studio that puts player in the (Kasedo Game: shoes of an early 20th2018) century industrialist"
"Design the city by building houses, streets and green spaces, employ citizens in offices and industrial plants while observing the effect climate of the city" of these actions on the
The player is challenged to make a critical decision to make an environmentalfriendly city
"The game starts with carbon raining down through the atmosphere (and ocean), while the player uses the photosynthesis of plants to control the uptake of atmospheric carbon"

The player is given a deck of cards containing resources, utilities, and tools.

Cards such as farms and industry produce money, utilities like generators and power plants provide energy that some cards need as requirements to be picked
Players need to shoot the $\mathrm{CO}^{2}$ particles that are released to the environment. As too much $\mathrm{CO}^{2}$ that the player missed, the temperature will rise and it will make the Earth flooded

Player need to carefully making decision before picking their card in order to avoid destruction in the ecosystem
The evaluation of the city will give the information to the player about the impact of the city that they have created. With the evaluation given, player will gain knowledge about suburbanization and its effects on environment. The game does not specify on carbon cycle process but it teaches the players about the effect of their action to the city

By playing this game player will gain knowledge about the effect of $\mathrm{CO}^{2}$ to the environment. It is a good game that display the carbon cycle to the player but it does not represent the whole carbon cycle process

Even though, it does not cover about carbon cycle process but by playing this game, player can gain knowledge on the relationship between the actions committed by humanity and its effect on the change in temperature. The player has a choice between exploiting the planet and destroying the ecosystem with risks of flooding or stall it as long as possible with environmentally friendly options.

The player must reflect sunlight back into space. If sunlight strikes the surface, the heat bar will go up.

When the bar is full, the game is over

\section{As the game} progresses to the next level, the number of $\mathrm{CO}^{2}$ particles spawned increases and the ice platform the player use decreases in size. Making it harder to reflect back light or causing the reflected light to still raise the heat level

"Player need to build and manage their growing empire in a living, breathing, and procedurally generated world that is constantly evolving and adapting to their playstyle"
Once hit a specific level, pollution will destroy housings and reduce the product output of farms. Player need to control the pollution by adding environmental
Player can learn about albedo phenomenon while playing this game.

On Thin Ice is a simple yet meaningful game as it explains the effect of global warming to the Earth. It explains the effect of excessive intake of carbon to the Earth

It does not focus on carbon cycle process but it is up to the player to choose a path for their own world, with this player will learn that every move or choice that they made will have an impact to the environment 
Oxygen Not "In the space-colony

Included by simulation game

Klei Oxygen Not Included

Entertainment player will find that

(Klei scarcities of oxygen,

Entertainment, warmth and

2017) sustenance are constant threats to player colony's survival"
Cities: Skylines "The game introduces by Colossal new gameplay Order Ltd. elements, allowing (Paradox player to experience Interactive, the thrill and 2015) hardships of creating and maintaining a real city"

SimCity 4 by A city builder Maxis simulation game that (Electronic Art allows the player to 2003) plan and build a city with a more freeform ancasual intensity up a proper base by ordering the workers to start harvesting resources, build a fully functional base, install the necessities such as wiring, plumbing, and controls by themself. Once a proper base is up and running, the player shall begin work on researching new equipment and upgrades
The player will need to set

building in order to reduce pollution

The game has several The focus of this game is mechanics that the player must be aware of such as workers' needs like food, health, and mental state, the base's temperature, switches, and electricity, and other mechanics like gas cycles"

The player starts by designing road layouts for their city and managing city zones by residential, economical, and industrial. The player shall then implement and handle basic demands of their citizens such as power, water supply, sewage, traffic congestion, pollution, and policies

A city simulation game that allows the player to plan, build, and manage their own city
Player need to be in control of the city that they had built in order to avoid pollution rising because it will cause the citizens to become ill and potentially die

The player must fulfill the demands of their citizens such as residential needs, workplaces, and industry not about carbon cycle but it does simulate the relationship between gas type, pressure, humidity and temperature on an immensely complex scale. With this simulation it is best suited to carbon cycle which is important to understand in order to know the causes of climate change.

Player can gain knowledge on the importance of proper management and planning to handle harmful gas production and elimination.

The game also describes multiple harmful substances that contributed to pollution including carbon dioxide, sulfur, and pollutants like smoke The game mechanic teaches how a well-planned city and living area is necessary for a clean and healthy environment. While it does not focus on carbon cycle process but player can relate it with real life situation of what will happen to the people if the rate of pollution in the world is worsen.

Air pollution is a mechanic that exists in this game. Factories and oil or coal power plant release an area of pollution around them. As pollution rises, the land value in that area will lower.

If the pollution becomes too strong, acid rain will start forming. These rains will cause damages to other buildings and infrastructures

To summarise, the requirements for CC game gathered from analysis of literature and available games are; 1) Contextualize the whole processes of carbon cycle as the main story, 2) Apply a combination of aesthetic pleasure and a good information of carbon cycle process, 3) Embed quiz into the game, 4) Add reward mechanism, rules and goals into the game, 5) Implement leaderboard, performance graph and badge in the game design. 


\section{CONCLUSION}

In conclusion, the first requirement of $\mathrm{CC}$ game gained from further literature analysis on $\mathrm{CC}$ issues and existing $\mathrm{CC}$ games is to contextualize the whole processes of carbon cycle as the main story of the game. The $\mathrm{CC}$ game must have a decent game design in a way that the carbon cycle information that is abstracted can be convey to the players effectively. A good game design can benefit players to understand its content that is portrayed through the game. The game design that is effective does not only depend on its fascinating art but there are also other elements that will strengthen it. Therefore, the next requirement for CC game is to adopt the combination of aesthetic pleasure and a good information on the whole processes of carbon cycle.

In addition, the use of quiz can motivate players to play $\mathrm{CC}$ game, motivate players' willingness to learn while playing serious game Thus, there is a requirement for $\mathrm{CC}$ game to apply the quiz concept in order to stimulate players' motivation and understanding. Moreover, the use of different kind of elements in the game design can trigger different psychological experience to the players. Elements in a good game design can bring satisfactions to the players when they play the game. Different elements in a game design such as stories, characters and leaderboards can bring different positive psychological experience to the players. Hence, there is a requirement for the $\mathrm{CC}$ game to add leaderboard, performance graph and badges in the game design in order to give a positive impact to the players' psychological needs.

The players might become more motivated to play and learn if they earn a reward after accomplishing a certain task in the game. Rewarding mechanism is a crucial part of the game design in order to promote a desired behavior or attitude in serious game that can directly affect the game experience (Sekhavat 2019). The CC game must have rewarding mechanism, rules and goals stimulate players' emotional state and behavior. For future work, we will formulate a CC game framework for climate change game based on the requirements, elements, factors and criteria, and to propose a new climate change game concept before constructing prototypes.

\section{REFERENCES}

Alonso-fernandez, C., Calvo, A., Freire, M., Martinez-ortiz, I. \& Fernandez-manjon, B. 2017. Systematizing game learning analytics for serious games (April), 1111-1118.

Alyson Wyers. 2016. Carbon Runner is an Endless Runner Video Game About Climate Change https://www.trendhunter.com/trends/carbon-runner [access on 1 May 2020]

Aqilah Mior Kamarulbaid. 2018.Kesedaran teknologi hijau masih rendah. http://www.utusan.com.my/sainsteknologi/teknologi/kesedaran-teknologi-hijau-masihrendah-1.729413 [access on 17 Feb 2019]

Bofferding L., Kloser M. (2015). Middle and high school students' conceptions of climate change mitigation and adaptation strategies. Environmental Education Research, 21, 275-294. doi:10.1080/13504622.2014.888401

Dondlinger, M. J. 2014. Educational Video Game Design : A Review of the Literature (January 2007), $20-31$.

Electronic Arts. 2003. https://www.ea.com/games/simcity/simcity-4 [access on 7 May 2020]

Foltz, A., Williams, C., Gerson, S. A., Reynolds, D. J., Pogoda, S., Begum, T., Walton, S. P. et al. 2019. Game Developers' Approaches to Communicating Climate Change 4(June). doi:10.3389/fcomm.2019.00028

Frank, D., Reichstein, M., Bahn, M., Thonicke, K., Frank, D., Mahecha, M. D., Smith, P. et al. 2015. Effects of climate extremes on the terrestrial carbon cycle: concepts, processes and potential future impacts (January), 2861-2880. doi:10.1111/gcb.12916

Games4Sustainability. Urban Climate Architect https://games4sustainability.org/gamepedia/urbanclimatearchitect/ [access on 4 May 2020]

Galloway, J. N., W. H. Schlesinger, C. M. Clark, N. B. Grimm, R. B. Jackson, B. E. Law, P. E. Thornton, A. R. Townsend, and R.Martin. 2014. Ch. 15: Biogeochemical Cycles. Climate Change Impacts in the United States: The Third National Climate Assessment, J. M. Melillo, Terese (T.C.) Richmond, and G. W. Yohe, Eds., U.S. Global Change Research Program, 350-368. doi:10.7930/J0X63JT0.]

Green Ninja. 2018. https://greenninja.org/resources [access on 1 May 2020]

Hopeless Production, 2018. Climate Cards https://rotomster.itch.io/climate-cards [access on 4 May 2020]

Iten, N. \& Petko, D. 2016. predictor of learning success ?47(1), 151-163. doi:10.1111/bjet.12226

Karn Bianco. 2018. https://karnbianco.itch.io/on-thin-ice [access on 5 May 2020] 
Kasedo Games. 2018 https://www.riseofindustry.com/ [access on 5 May 2020]

Klei Entertainment. 2017. https://www.kleientertainment.com/games/oxygen-not-included [access on 7 May 2020]

Meya, J.N. and Eisenack, K. 2018. Climatic Change 149: 319. https://doi-org.ezplib.ukm.my/10.1007/s10584-018-2254-7 [accessed on 17 Feb 2019]

Oliver Franklin-Wallis. 2017. 'Eco' is a survival game with a difference: it wants to save the world https://www.wired.co.uk/article/strange-loop-games-eco-simulation [access on 5 May 2020]

Ouariachi, T., Dolores Olvera-Lobo, M., \& Gutiérrez-Pérez, J. 2017. Analyzing Climate Change Communication Through Online Games: Development and Application of Validated Criteria. Science Communication, 39(1), pp.10-44.

Paradox Interactive. 2015. https://www.citiesskylines.com/\#about [access on 7 May 2020]

Pidwirny, M, 2006. "The Carbon Cycle". Fundamentals of Physical Geography, 2nd Edition. http://www.physicalgeography.net/fundamentals/9r.html [access on 8 June 2020]

Plethora Project. 2016. https://www.plethora-project.com/blockhood [access on 5 May 2020]

Reckien, D. \& Eisenack, K. 2015. Climate Change Gaming on Board and Screen: A Review. doi:10.1177/1046878113480867

Rolle, F. 2018. seawater as a basis for climate change studies. 2018 IEEE International Workshop on Metrology for the Sea; Learning to Measure Sea Health Parameters (MetroSea), 99-103.

Sailer, M., Hense, J. U., Mayr, S. K. \& Mandl, H. 2017. SC. Computers in Human Behavior,. doi:10.1016/j.chb.2016.12.033

Sau, N., Weng, C. \& Ahamad, R. 2016. Environmental Awareness and Behaviour Index for Malaysia 222(7), 668-675. doi:10.1016/j.sbspro.2016.05.223

Sekhavat, Y. A. 2019. A Rewarding Framework for Multiplayer Serious Games based on Competitive Reinforcement. 2019 IEEE 7th International Conference on Serious Games and Applications for Health (SeGAH), 1-8.

Shahiddan Saidi. 2014. Kesedaran Isu Tenaga Dan Perubahan Iklim Rendah Dalam Kalangan Rakyat, http://www.ukm.my/news/arkib-berita/year-2014/februari-2014/kesedaran-isu-tenaga-dan-perubahan-iklim-rendahdalam-kalanganrakyat/ [accessed on 17 Feb 2019]

Shahino Mah Abdullah. 2018. https://www.bharian.com.my/rencana/komentar/2018/01/376558/peka-dalamtanganiperubahaniklim. [accessed on $17 \mathrm{Feb} 2019]$

Strange Loop Games. 2018. https://www.play.eco/ [access on 5 May 2020]

Videnovik, M., Kionig, L., Vold, T. \& Trajkovik, V. 2018. Testing framework for investigating learning outcome from quiz game. 2018 17th International Conference on Information Technology Based Higher Education and Training (ITHET), 1-5.

Videogames, C., Zou, Y. R., Mustafa, N., Memon, N. A. \& Eid, M. 2015. ECO ECO : Changing Climate Related Behaviors For.

Walsh, J., D. Wuebbles, K. Hayhoe, J. Kossin, K. Kunkel, G. Stephens, P. Thorne, R. Vose, M. Wehner, J. Willis, D. Anderson, S.Doney, R. Feely, P. Hennon, V. Kharin, T. Knutson, F. Landerer, T. Lenton, J. Kennedy, and R. Somerville, 2014: Ch. 2: Our Changing Climate. Climate Change Impacts in the United States: The Third National Climate Assessment, J. M. Melillo, Terese (T.C.) Richmond, and G. W. Yohe, Eds., U.S. Global Change Research Program, 19-67. doi:10.7930/J0KW5CXT.

Wyrwa, A. 2018. Climate Change Mitigation Game 21-25.

Zufri, T., Sn, S. \& Ds, M. 2016. Character Design as Bridging Tools of Ideological Message in Game. 